University of Nebraska - Lincoln

DigitalCommons@University of Nebraska - Lincoln

Roman L. Hruska U.S. Meat Animal Research

U.S. Department of Agriculture: Agricultural Center

Research Service, Lincoln, Nebraska

2000

\title{
Porcine $\lg$ A allotypes are not equally transcribed or expressed in heterozygous swine
}

\author{
P. Navarro \\ University of lowa \\ R.K. Christensen \\ USDA, ARC \\ P. Weber \\ University of lowa \\ M. Rothschild \\ University of lowa \\ G. Ekhardt \\ Pig Improvement Corporation \\ See next page for additional authors
}

Follow this and additional works at: https://digitalcommons.unl.edu/hruskareports

Navarro, P.; Christensen, R.K.; Weber, P.; Rothschild, M.; Ekhardt, G.; and Butler, J.E., "Porcine IgA allotypes are not equally transcribed or expressed in heterozygous swine" (2000). Roman L. Hruska U.S. Meat Animal Research Center. 206.

https://digitalcommons.unl.edu/hruskareports/206

This Article is brought to you for free and open access by the U.S. Department of Agriculture: Agricultural Research Service, Lincoln, Nebraska at DigitalCommons@University of Nebraska - Lincoln. It has been accepted for inclusion in Roman L. Hruska U.S. Meat Animal Research Center by an authorized administrator of DigitalCommons@University of Nebraska - Lincoln. 


\section{Authors}

P. Navarro, R.K. Christensen, P. Weber, M. Rothschild, G. Ekhardt, and J.E. Butler 


\title{
Porcine IgA allotypes are not equally transcribed or expressed in heterozygous swine ${ }^{\text {is }}$
}

\author{
P. Navarro ${ }^{\mathrm{a}, *}$, R.K. Christensen ${ }^{\mathrm{b}}$, P. Weber ${ }^{\mathrm{a}}$, M. Rothschild ${ }^{\mathrm{c}}$, G. Ekhardt ${ }^{\mathrm{d}}$, \\ J.E. Butler ${ }^{\mathrm{a}}$ \\ a Department of Microbiology, The University of Iowa, Iowa City, IA 52242, USA \\ ${ }^{\mathrm{b}}$ USDA, ARC, US Meat Animal Research Laboratory (MARC), Clay Center, NE 68933-0166, USA \\ ${ }^{\mathrm{c}}$ Department of Animal Science, Iowa State University, Ames, IA 50011, USA \\ d Pig Improvement Corporation (PIC), Franklin, KY, USA
}

Received 1 July 2000; accepted 11 October 2000

\begin{abstract}
The prediction of 1:1 expression of constant region allotypes in heterozygous animals assumes that productive VDJ rearrangements occur at random between chromosomes, switch recombination is random, there is no allele-related defect in switching and there is no selection for a B-cell receptor bearing a certain constant region allotype. In data reported here, this prediction was often not fulfilled for the transcripts encoding the $\operatorname{Ig} \mathrm{A}^{\mathrm{a}}$ and $\operatorname{Ig} \mathrm{A}^{\mathrm{b}}$ alleles of porcine $\operatorname{IgA}$ including those from late term fetal piglets that are not in contact with environmental antigens or maternal regulatory factors. In the spleen, thymus, mesenteric lymph node (MLN), ileal Peyer patches, parotid gland and PBLs of 5-week-old conventionally-reared Duroc pigs, ratios of $\operatorname{Ig} \mathrm{A}^{\mathrm{a}}$ to $\operatorname{Ig} \mathrm{A}^{\mathrm{b}}$ transcripts as high as 4:1 were observed. Since White Cross animals had significantly higher levels of IgA than $\operatorname{IgA}^{\mathrm{a}}$ (some $>3$-fold), a allele-linked switch defect cannot explain the deviation from the expected 1:1 ratio. When the $\operatorname{Ig} A^{\mathrm{a}}: \operatorname{Ig} \mathrm{A}^{\mathrm{b}}$ ratios in older Durocs and those reared at a different site were studied, no evidence for breed dependence of differential transcription was found. Total serum IgA levels paralleled total transcript levels in PBLs while particularly in White Cross animals, the $\operatorname{Ig} A^{\mathrm{a}}: \operatorname{Ig} \mathrm{A}^{\mathrm{b}}$ ratio in serum was higher in many animals than the $\operatorname{Ig} \mathrm{A}^{\mathrm{a}}: \operatorname{Ig} \mathrm{A}^{\mathrm{b}}$ transcript ratio in their PBLs. We conclude that deviations from the expected 1:1 ratio of allotype transcripts and secreted $\operatorname{IgA}$ in young pigs is normal and deviations from this ratio also occur during fetal life in the absence of environmental antigens and maternal regulatory factors. We speculate that postnatal deviations result from: (a) exposure to environmental antigens that selectively expand B-cells expressing $\mathrm{V}_{\mathrm{H}}$ gene alleles linked to either $\operatorname{IgA}^{\mathrm{a}}$ or $\operatorname{IgA}^{\mathrm{b}}$ or (b) some form of colostrum-dependent regulation. Pre-natal regulation may depend on the selection of B-cells bearing certain $\mathrm{V}_{\mathrm{H}}$ or $\mathrm{C}_{\mathrm{H}}$ encoded BCRs by stromal ligands such as fetal B-cell superantigens. (C) 2001 Elsevier Science Ltd. All rights reserved.
\end{abstract}

Keywords: Porcine IgA allotypes; Transcribed; Expressed; Heterozygous swine

\section{Introduction}

Immunoglobulin (Ig) allotypes behave as co-dominant Mendelian alleles in all cases that have been so far reported (Grubb, 1994). Surface expression of the $\mathrm{C} \mu$

\footnotetext{
Mention of trade names or commercial products in this article is solely for the purpose of providing specific information and does not imply recommendation or endorsement by the US Department of Agriculture.

* Corresponding author. Tel.: +1-319-3357776; fax: + 1-3193359006.

E-mail address: jebutler@blue.weeg.uiowa.edu (P. Navarro).
}

heavy chain in association with the gene product of a successfully rearranged VDJ inhibits further attempts by the developing B-cell to rearrange the VDJ of the other chromosome (Melchers et al., 1994). Thus, it has been generally taught that each B-cell expresses the product of only one chromosome, i.e. a haplotype of genes encoding the productive VDJ rearrangement and the cis encoded constant heavy chain. This is the basis of 'allelic exclusion' and selection of one haplotype over the other is thought to be random. On the basis of this concept, heterozygotes should have equal numbers of B-cells expressing the products of each haplotype unless there has been selective proliferation of those expressing 
the gene product of one haplotype. Since it has been estimated that up to 20 million B-cells leave the bone marrow and enter the peripheral circulation each day (Janeway and Travers, 1996) and in humans 2.5\% are $\operatorname{IgA}(+)$ (L. Hammerstrom, personal communication), RNA extracted from $10 \mathrm{ml}$ of blood should contain IgA transcripts from $>20000$ B-cells. With so many cells and if transcription is random, the probability that a deviation exceeding a 47:53 ratio of Ig haplotypes in a heterozygote could occur by chance is $<0.01$.

Despite theoretical arguments, there have been reports of unequal allotype expression. Differences in $\mathrm{C}_{\mathrm{H}}$-region allotype expression were first reported by Yount et al. (1967). They observed that IgG3 levels were correlated with the G3m allotypes, namely high levels of $\mathrm{IgG} 3$ were associated with $\mathrm{G} 3 \mathrm{~m}^{\mathrm{b}}$ and low levels with $\mathrm{G} 3 \mathrm{~m}^{\mathrm{g}}$. This was corroborated by others (Morel et al., 1972; Hassan et al., 1992) and was eventually shown to result from differential switching due to a point mutation in $\mathrm{S} \gamma 3$ (Pan et al., 1997). Switch region differences have also been implicated in the differential expression of IgG4 alleles in humans (Pan et al., 1998). In rabbits, in which the a-allotypes are encoded by $\mathrm{V}_{\mathrm{H}} 1$, up to 4-fold more a1- than a2-bearing $\operatorname{IgG}$ has been reported in a1/a2 heterozyzgotes (Mage, 1977).

Swine have a single gene for IgA (Brown and Butler, 1994) which occurs in two allelic forms, $\operatorname{Ig} A^{a}$ and $\operatorname{Ig} A^{b}$ (Brown et al., 1995). The genes encoding the heavy chain of both alleles are identical in sequence except for a splice acceptor site mutation in $\operatorname{Ig} \mathrm{A}^{\mathrm{b}}$ that results in loss of most of the $\operatorname{IgA}^{\mathrm{b}}$ hinge. Because of the likelihood that changes in the hinge might effect function, the immunobiology of these allotypes is under investigation.

The ratio of transcripts for the porcine $\operatorname{Ig} \mathrm{A}^{\mathrm{a}}$ and $\operatorname{Ig} \mathrm{A}^{\mathrm{b}}$ allotypes in heterozygous fetal piglets and in young conventional pigs of various ages and breeds is reported here. Transcript ratios can be skewed more than 3:1 in either direction and is apparently not breed dependent. The skewed transcript ratios is inconsistent with the idea of a shorter transcript half-life for one allele or a defect in switch $\alpha(\mathrm{S} \alpha)$ of either $\operatorname{Ig} \mathrm{A}^{\mathrm{a}}$ or $\operatorname{Ig} \mathrm{A}^{\mathrm{b}}$. We suggest that the influence of enviornmental antigens, stromal ligands or passive maternal regulatory factors most likely explain these results.

\section{Materials and methods}

\subsection{Source of animals}

Blood and tissue samples were collected from Duroc pigs at Iowa State University (ISU), PBLs from White Cross animals at the Meat Animal Research Center (MARC), PBLs from Duroc animals at the Pig Im- provement Corporation, Franklin, KY, and various lymphoid tissue from late term White Cross fetuses at MARC. All animals were genotyped by RFLP (Brown et al., 1995; Navarro et al., 2000).

\section{2. $R N A$ and $c D N A$ preparation}

RNA was extracted from tissue crushed in liquid nitrogen and homogenized in TriZol Reagent (Molecular Research Center, Cincinnati, $\mathrm{OH}$ ) according to the manufacturer's protocol. The integrity of the extracted RNA was verified by staining with ethidium bromide after agarose gel electrophoresis and by spectrometry. First strand complementary DNA (fscDNA) was synthesized from $10 \mu \mathrm{g}$ of total RNA using an anti-sense $\mathrm{C} \alpha 3$ primer specific for the $5^{\prime}$ end of the $\mathrm{C} \alpha 3$ exon. Simultaneously an antisense primer (5'-CTC CGT GAG GAT CTT CAT GA-3') that binds in the $3^{\prime}$ region of porcine $\beta$-actin was used to synthesize $\beta$-actin fscDNA. The master reaction mix contained $40 \mathrm{U}$ RNasin, $5 \mu \mathrm{g}$ BSA, $150 \mathrm{pmol}$ of the antisense primer, and $200 \mathrm{U}$ MMLV reverse transcriptase. The RNA was denatured at $70^{\circ} \mathrm{C}$ in DEPC water before adding it to the master reaction mix. The samples were incubated at $37^{\circ} \mathrm{C}$ for $1 \mathrm{~h}$ and then frozen at $-20^{\circ} \mathrm{C}$.

\subsection{Determination of allotype transcript ratios}

Oligonucleotide primers were used to amplify a segment of the $\mathrm{C} \alpha$ gene. These primers allow a segment between position $281^{1}$ in the first domain (5'-CCGTGAACGTGCCCTGCAAAG-3') and position $533^{1}$ (positions in genomic sequence that span the intron between $C \alpha 1$ and $C \alpha 2$ (Brown and Butler, 1994)) in the second domain (5'-GAGCCCAGGAGCAGGTCT-3') to be amplified. The antisense $\mathrm{C} \alpha 2$ primer was end-labeled with $\left[{ }^{32-\mathrm{P}} \gamma\right] \mathrm{ATP}$, and used at a proportion of 9 parts unlabeled primer for each part of labeled primer. The fscDNA $(5 \mu \mathrm{l})$ was then used as the template for the PCR. As an internal PCR control and to calculate values for 'total relative transcription' among samples (see below), a 135 bp $\beta$-actin fragment was simultaneously amplified using $150 \mathrm{pmol}$ of an $\beta$-actin sense primer (5'-ATT GTC ATG GAC TCT GGG GA-3') and an end-labeled antisense primer (5'-ACA GCG AGG CCA GGA TGG AG-3'). Use of actin primers did not influence amplification of IgA or visa-versa. The size of the three expected PCR products is $106 \mathrm{bp}$ for the $\operatorname{Ig} \mathrm{A}^{\mathrm{a}}$ allotype, $94 \mathrm{bp}$ for the $\operatorname{Ig} \mathrm{A}^{\mathrm{b}}$ variant, and $135 \mathrm{bp}$ for $\beta$-actin (Fig. 1A). The reaction mixture contained $100 \mathrm{ng}$ fscDNA, $150 \mathrm{pmol}$ of primers, $67 \mu \mathrm{M}$ each of $\mathrm{dNTP}, 1 \mathrm{mM} \mathrm{MgCl}$, and $1 \mathrm{U}$ of Taq polymerase in a $30 \mu \mathrm{l}$ volume. Reaction conditions for a $\mathrm{MJ}$

\footnotetext{
${ }^{1}$ Positions in genomic sequence that span the intron between $\mathrm{C} \alpha 1$ and C $\alpha 2$ (Brown and Butler, 1994).
} 
PTC-200 thermocycler were: $94^{\circ} \mathrm{C}$ for $3 \mathrm{~min}$ followed by 35 cycles of denaturating at $94^{\circ} \mathrm{C}$ for $5 \mathrm{~s}$, annealing at $62^{\circ} \mathrm{C}$ for $30 \mathrm{~s}$, and extension at $72^{\circ} \mathrm{C}$ for $5 \mathrm{~s}$. A final extension cycle was performed at $72^{\circ} \mathrm{C}$ for $5 \mathrm{~min}$. The PCR products were analyzed in triplicate by separating the fragments in a $6 \%$ polyacrylamide gel containing 8 $\mathrm{M}$ urea (Fig. 1A). The PCR product $(1 \mu \mathrm{l})$ was denatured at $95^{\circ} \mathrm{C}$ in the presence of $80 \%$ formamide gel loading buffer prior to electrophoresis at $65^{\circ} \mathrm{C}$. After electrophoresis for $40 \mathrm{~min}$, the gel was scanned in a Packard instant imager and the instant imager electronic autoradiography program (Packard) used to normalize the IgA allotype signals with that of the signal from the $\beta$-actin fragment to account for any variations in gel loading and efficiency of PCR (Fig. 1A). PCR products yielded counts $20-40$-fold higher than background and although the amplified product of $\operatorname{Ig} \mathrm{A}^{\mathrm{b}}$ migrated faster than that for $\operatorname{IgA}^{\mathrm{a}}$ (Fig. 1A), the difference in migration rate had no effect on the intensity of the radioactive signal.

\subsection{Total relative transcription of $\operatorname{Ig} A$}

Differences in IgA transcription among various samples and tissues were determined relative to that of $\beta$-actin by calculating the ratio of ${ }^{32} \mathrm{P}$ activities for $\operatorname{IgA} / \beta$-actin, $\operatorname{Ig} A^{\mathrm{b}} / \beta$-actin or in the case of heterozygotes, $\operatorname{Ig} \mathrm{A}^{\mathrm{a}}+\operatorname{Ig} \mathrm{A}^{\mathrm{b}} / \beta$-actin.

\subsection{Validation of the $R T-P C R$ assay for comparing allotype transcription}

To determine if the RT enzyme would transcribe both allotypes at the same rate and/or efficiency, a set of RT-PCRs were performed using mixtures containing known quantities of RNA isolated from homozygous animals of each allotype (Fig. 1B).
In addition, we wished to identify possible sources of variability within the RT-PCR assay through hierarchical analysis of variance (nested ANOVA; Lyman (1993)). This test of validity consisted of performing three RNA extractions from the same tissue sample in three heterozygous animals (Fig. 2). Each RNA sample was then used as the template for three fscDNA synthesis reactions. Finally, each fscDNA was in turn used in three PCRs, and the ratio between the $\operatorname{Ig} \mathrm{A}^{\mathrm{a}}$ and $\operatorname{Ig} \mathrm{A}^{\mathrm{b}}$ products was used as the read-out for the analysis. Variance at each level (tissue, RNA or cDNA) was calculated using the fully nested ANOVA function of release 12.2 of the Minitab statistical software package (Minitab). All factors were implicitly assumed to be random. Minitab uses sequential (Type I) sums of squares for all calculations.

\subsection{Measurement of total serum IgA}

Total serum IgA was measured by sandwich ELISA using the globulin fraction of rabbit anti-swine IgA (B5321) as the capture antibody, mouse monoclonal anti-swine IgA for detection (mAb1459) and a rabbit anti-mouse alkaline phosphatase conjugate (Sigma, St. Louis) to deliver the signal. Monclonal 1459 anti-IgA was kindly provided by Dr Klaus Nielson (Animal Disease Research Institute, Nepean, Ont., Canada). Purified porcine IgA was available in the laboratory for use as a standard.

\subsection{Determination of the serum concentration of $\operatorname{Ig} A^{a}$ and $\operatorname{Ig} A^{b}$}

Monoclonal 27.8.1 (A. Bianchi, Lelystad, The Netherlands) was selected from a panel of six mouse anti-swine IgA mAbs because of its bias for detecting
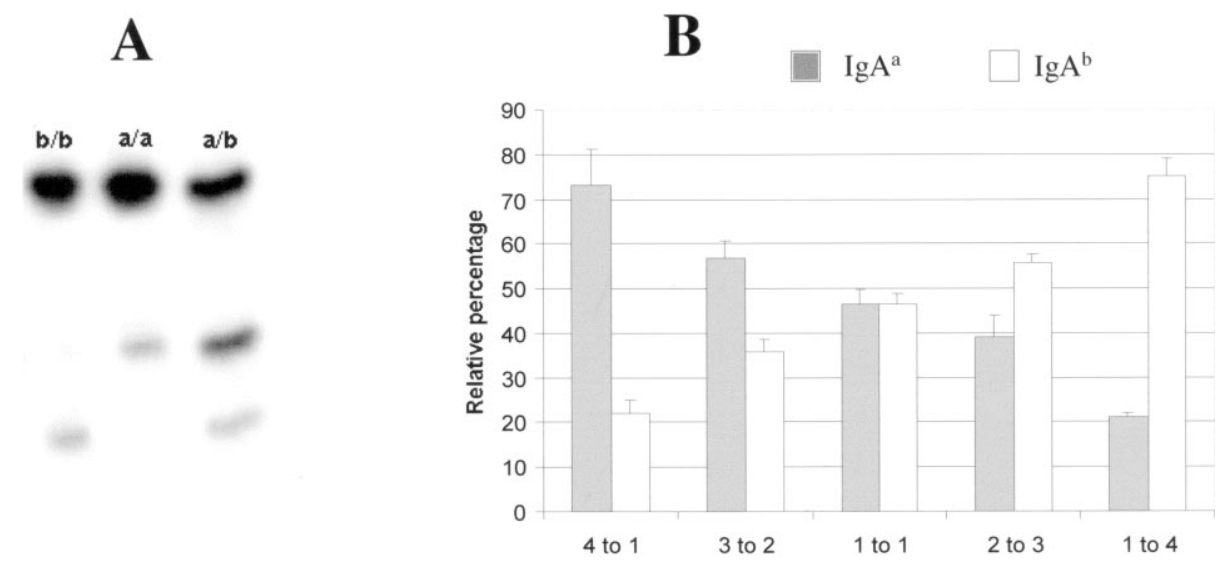

Fig. 1. (A) Electrophoretic separation of transcription fragments of $\operatorname{Ig} \mathrm{A}^{\mathrm{a}}, \operatorname{Ig} \mathrm{A}^{\mathrm{b}}$ and $\beta$-actin generated by RT-PCR. The larger heavy upper band is that of the $\beta$-actin transcript product. (B) Transcription efficiency of RT-PCR for IgA ${ }^{\mathrm{a}}$ and $\operatorname{IgA}^{\mathrm{b}}$. Purified total RNA from homozygous IgA and $\operatorname{IgA}^{\mathrm{b}}$ animals was mixed in the proportions indicated on the $X$-axis. These were then subjected to RT-PCR and the radioactivity in the allotype-specific polynucleotides expressed on the $Y$-axis as the percentage of total IgA transcripts recovered. Each sample was tested three times and the results presented are the mean and S.D. 


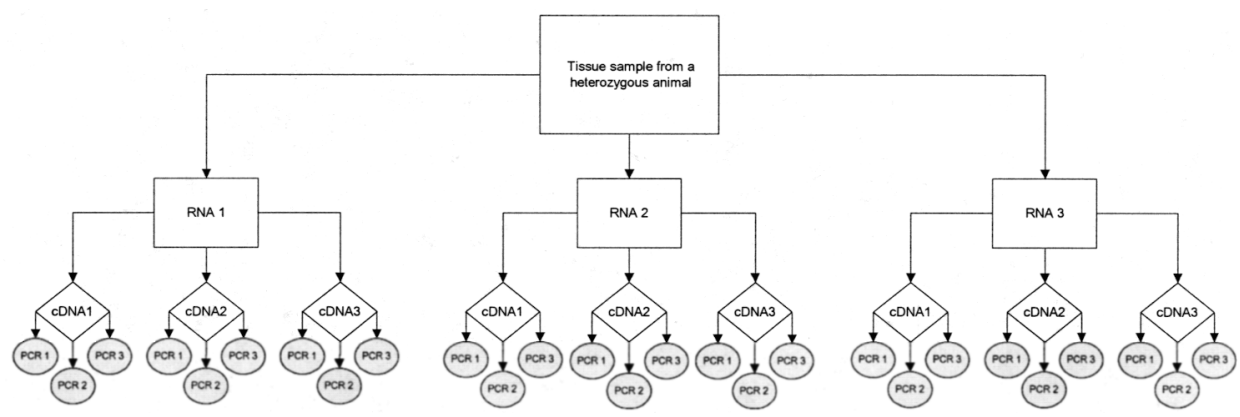

Fig. 2. Hierarchical design for analysis of variance. Three independent RNA extractions were initially performed from one tissue of a randomly selected heterozygous animal. Each RNA was used in three separate cDNA synthesis reactions, and each of the resulting cDNAs were used as the template for a PCR reaction with the IgA primers. The same experiment was repeated except that in the second test, the same tissue from three different animals was used. These animals were randomly selected with respect to their $\operatorname{Ig} \mathrm{A}^{\mathrm{a}}: \operatorname{Ig} \mathrm{A}^{\mathrm{b}}$ ratios.

$\operatorname{Ig} \mathrm{A}^{\mathrm{a}}$ (Navarro, 1998). Mixtures of sera homozygous for $\operatorname{IgA}^{\mathrm{a}}$ and $\operatorname{Ig} \mathrm{A}^{\mathrm{b}}$, for which the total $\operatorname{IgA}$ content had been determined, were prepared at ratios of $4: 1,3: 2$, $1: 1,2: 3$, and 1:4. These were then tested in a sandwich ELISA identical to that described above, except that $\mathrm{mAb} 27.8 .1$ was used for detection. The slope of the standard curve obtained with the mixtures described above was then calculated by linear regression and used to determine the proportion of $\operatorname{IgA}{ }^{\mathrm{a}}$ in unknown samples. $\operatorname{Ig} \mathrm{A}^{\mathrm{b}}$ concentrations were then determined by subtraction of the calculated $\operatorname{Ig} \mathrm{A}^{\mathrm{a}}$ concentration from the total concentration of IgA determined as described above.

\subsection{Statistical analysis}

A number of different statistical methods were employed to compare the relative transcription of $\operatorname{Ig} \mathrm{A}^{\mathrm{a}}$ and $\operatorname{IgA}^{\mathrm{b}}$. In some cases we employed a split-plot ANOVA which tests the null hypothesis that $\operatorname{IgA}^{\mathrm{a}}$ and $\operatorname{Ig}^{\mathrm{b}}$ transcripts occur in equal amounts (Fig. 9) whereas simple $t$-tests were employed in most other cases. As described above, a hierarchical ANOVA based on the Minitab statistical software package was employed to determine the source of variation in the assay used to measure relative transcription.

\section{Results}

\subsection{Differences in $\operatorname{Ig} A^{a}: \operatorname{Ig} A^{b}$ transcript ratios determined by $R T-P C R$ represent animal differences}

The results of the hierarchical ANOVA of the RTPCR assay employed for comparing allotype transcription (Fig. 2) are given in Table 1. The results indicate that the major source of variability came from routine technical errors in performing the assay, e.g. pipetting (Table 1A). In spite of this variation, reproducibility of the $\operatorname{IgA}^{\mathrm{a}}: \operatorname{IgA}^{\mathrm{b}}$ ratios with this assay was very consistent, as indicated by the small standard deviation observed (note error bars in Figs. 1, 3-7 and 9). When the experimental test for variability was expanded by using tissues from three animals, analysis indicated that the intrinsic error in the system was reduced from $65 \%$ (Table $1 \mathrm{~A}$ ) to only $1.27 \%$ (Table $1 \mathrm{~B}$ ), i.e. variation is overwhelmingly due to difference in $\operatorname{IgA}^{\mathrm{a}}: \operatorname{IgA}^{\mathrm{b}}$ ratios among the three different heterozoygous animals.

Furthermore, we show that by varying the ratios of RNA from $\mathrm{a} / \mathrm{a}$ and $\mathrm{b} / \mathrm{b}$ animals, reverse transcription is equally efficient for both allotypes and the radioactivity of the $\operatorname{Ig} \mathrm{A}^{\mathrm{a}}$ and $\operatorname{Ig} \mathrm{A}^{\mathrm{b}}$ PCR products is directly proportional to the amount of each RNA added (Fig. 1B).

Table 1

Identification of the source of variation in $\mathrm{RT}-\mathrm{PCR}^{\mathrm{a}}$

\begin{tabular}{llcl}
\hline Source of variation & Var comp. & Total variation $(\%)$ & S.D. \\
\hline$A$ & & & \\
RNA & 0.002 & 22.19 & 0.041 \\
cDNA & 0.001 & 12.14 & 0.030 \\
Error & 0.005 & 65.67 & 0.070 \\
Total & 0.007 & & 0.086 \\
$B$ & & & \\
Animal & 0.298 & 98.33 & 0.546 \\
RNA & 0.001 & 0.21 & 0.025 \\
cDNA & 0.001 & 0.18 & 0.024 \\
Error & 0.004 & 1.27 & 0.062 \\
Total & 0.303 & & 0.551 \\
\end{tabular}

a (A) ANOVA to identify the source of variation in the determination of the ratio of $\operatorname{Ig} \mathrm{A}^{\mathrm{a}}$ to $\operatorname{Ig} \mathrm{A}^{\mathrm{b}}$ transcription. The contribution to variability of each component of the assay is shown. The table was generated by the Minitab program. Var comp, variance component. (B) Variance components of the ANOVA generated when testing the same tissue from three different animals. The major source of variation in RT-PCR is due to different animals that have different ' $a$ ' to ' $\mathrm{b}$ ' transcript ratios. This experiment tests the assumption that the variation attributed to RNA extraction or cDNA synthesis will not affect the validity of the assay, but rather the difference observed in ' $a$ ' to ' $b$ ' ratios in different animals is the result of real variation in $\mathrm{a} / \mathrm{b}$ ratios. 
A. Animal 1310

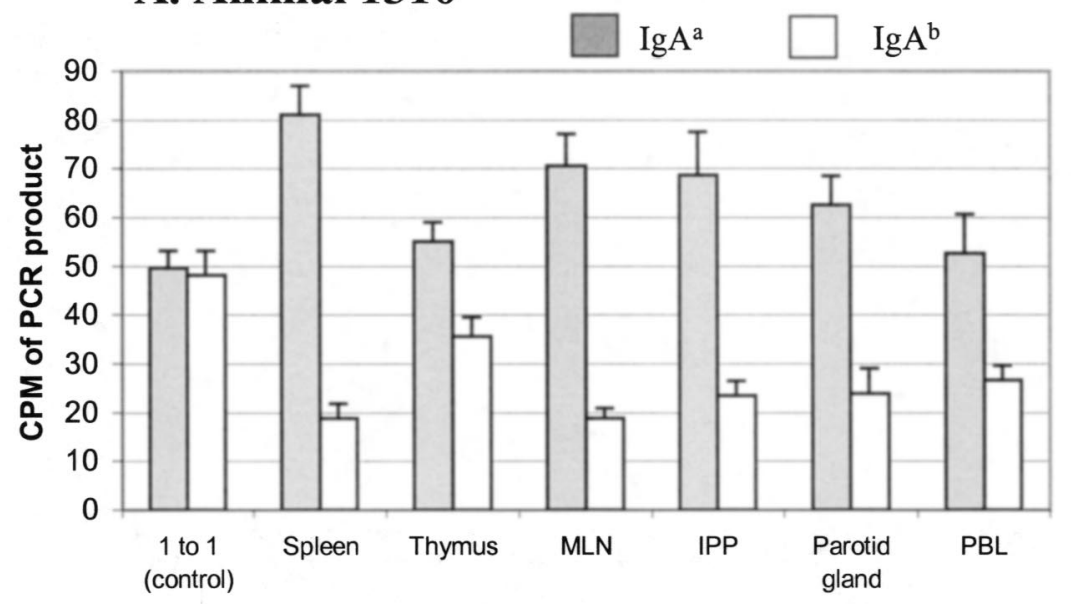

B. Animal $1303 \quad \square \operatorname{Ig} A^{\mathrm{a}} \quad \square \operatorname{Ig} \mathrm{I}^{\mathrm{b}}$

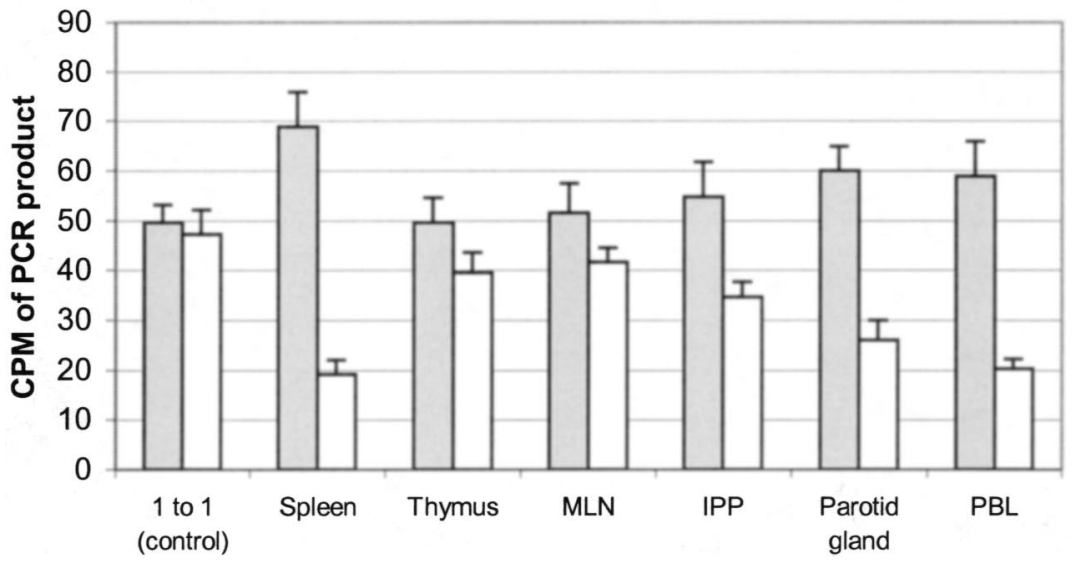

Fig. 3. Comparative transcription of $\operatorname{IgA}^{\mathrm{a}}$ and $\operatorname{IgA}{ }^{\mathrm{b}}$ in various lymphoid tissues from two 5-week-old Duroc heterozygotes. The results are expressed as the mean of triplicate measurements plus the S.D. The sample labeled control is the product of an RT-PCR performed with purified RNA obtained from homozygous $\operatorname{IgA}^{\mathrm{a}}$ and $\operatorname{Ig} \mathrm{A}^{\mathrm{b}}$ animals that was mixed in equal amounts (see also Fig. 1B). Differences were significant at the 0.05 level for animal 1310 using Student's $t$-test with 4 d.f. The observed values of $t$ were $8.74,3.18,7.75,5.03,4.48$ and 4.14 for the various tissues (left to right). In the case of animal 1303, the differences in transcript expression were significant at 0.05 for spleen $(t=6.08)$, parotid $(t=6.01)$ and PBLs $(t=5.36)$.

\subsection{The $\operatorname{Ig} A^{a}: \operatorname{Ig} A^{b}$ transcript ratio can significantly deviate in both directions in conventionally-reared heterozygotes}

When the ratio of $\operatorname{IgA}^{\mathrm{a}}: \operatorname{IgA}^{\mathrm{b}}$ transcripts recovered from the PBLs of young heterozygous Duroc piglets from ISU was examined, we were surprised to see that the ratio was skewed to favor $\operatorname{IgA}^{\mathrm{a}}$. Therefore, two 5-week-old heterozygotes were euthanized ( \# 1310 and 1303) and $\operatorname{IgA}$ allotype transcription studied in a number of lymphoid tissues (Fig. 3). In the spleen transcripts for $\operatorname{IgA}^{\mathrm{a}}$ outnumbered those of $\operatorname{IgA}^{\mathrm{b}} \quad 4: 1$. Considering all tissues tested the transcription of $\operatorname{Ig} \mathrm{A}^{\mathrm{a}}$ was $>2$-fold higher than for $\operatorname{IgA}^{\mathrm{b}}$ in animal \# 1303 and $>2.5$-fold higher in animals \# 1310. This result indicated that what we had observed for PBL transcripts was representative of all lymphoid tissues. Therefore, we proceeded to investigate allotype transcript ratios in PBLs of other herds. First we wondered whether the skewed transcript ratios were common to all swine, only Durocs or only Durocs from the 5-weekold litter that we had initially studied. Eight-week-old Duroc from ISU had nearly equal ratios (data presented in part in Fig. 7B). In the PBLs of heterozygous White Cross animals from MARC, 21 of 23 had higher levels of $\operatorname{IgA}^{\mathrm{b}}$ than $\operatorname{IgA}^{\mathrm{a}}$ transcripts. Treated as a group, $\operatorname{Ig} \mathrm{A}^{\mathrm{b}}$ levels were significantly higher than $\operatorname{IgA}^{\mathrm{a}}$ levels (Fig. 4). In several animals the $\operatorname{Ig} A^{\mathrm{b}}: \operatorname{IgA}^{\mathrm{a}}$ ratio was $>3: 1$. We also tested 14 young heterozygous Duroc pigs from Franklin, KY, and found that the 
$\operatorname{Ig} A^{\mathrm{a}}: \operatorname{Ig} \mathrm{A}^{\mathrm{b}}$ transcript ratios in their PBLs did not statistically differ from 1:1 (Fig. 5).

\subsection{Total relative IgA transcription differs among tissues but is not genotype dependent}

While the $\beta$-actin product remained relatively constant among the different tissues and animals tested, the levels of IgA transcripts differed significantly among tissues thus resulting in major differences in total relative transcription (Fig. 6). IgA expression was highest in the parotid glands (a major secretor of $\operatorname{IgA}$ ) and lowest in the PBLs.

\subsection{Total serum IgA levels parallel total relative} transcript levels in PBLs while the ratios of allotype transcripts differ

Since it is known that transcripts may have different half-lives, the level of transcription may not correlate with the level of protein expression. When relative IgA transcription in PBL and total IgA serum levels were compared, a significant correlation was found, regardless of allotype (Fig. 7A). Differences between the ratio of allotype transcription and allotype expression, i.e. serum concentration, were further compared in eight heterozygous piglets of different breeds and from different farms. Tested in this manner, the ratio of allotype-
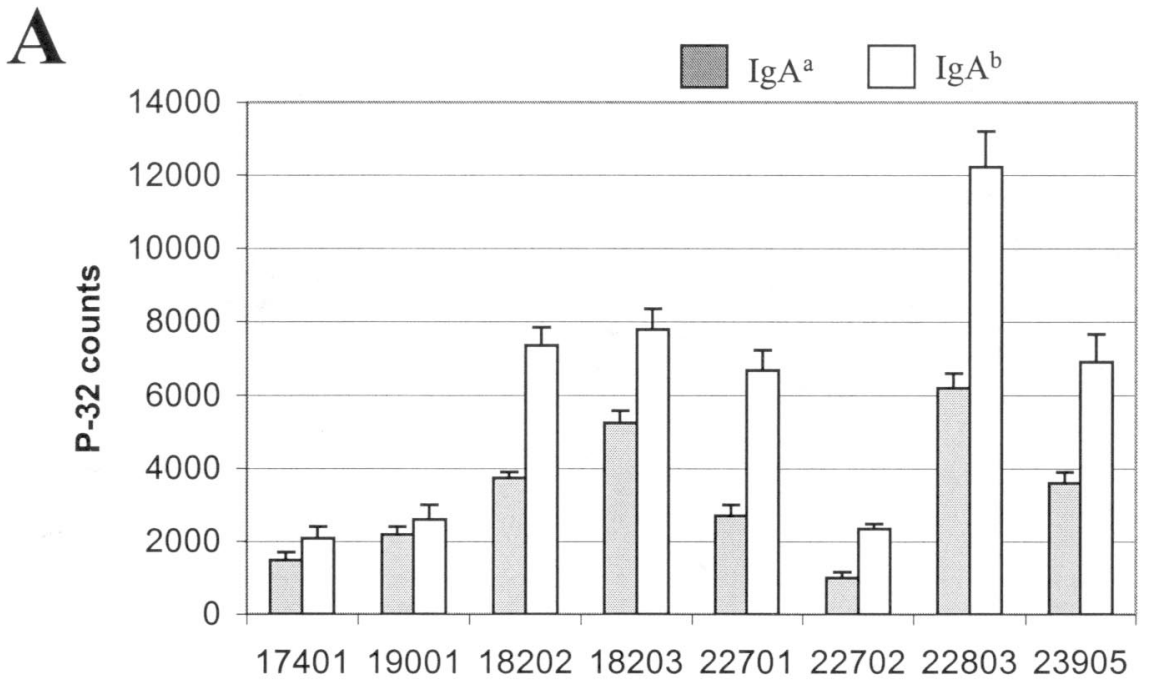

Pig Number
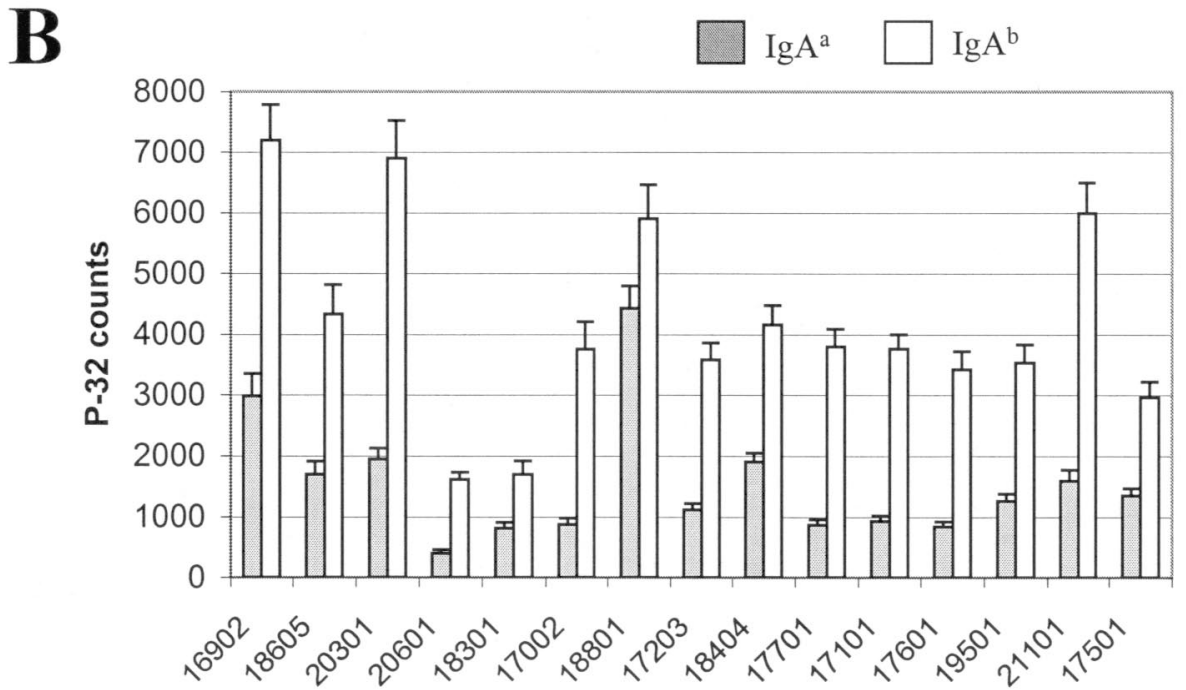

Pig Number

Fig. 4. Relative transcription of the IgA allotypes in the PBLs from young White Cross heterozygotes. The results are expressed as the mean and S.D. The $Y$-axis indicates the total corrected counts for each PCR product. Treated as a group, IgA ${ }^{\mathrm{b}}$ transcripts were expressed at significantly higher levels than $\operatorname{IgA}^{\mathrm{a}}$ when tested in a two way ANOVA model where the observed $F=72.7$ and $P=0.0001$. 


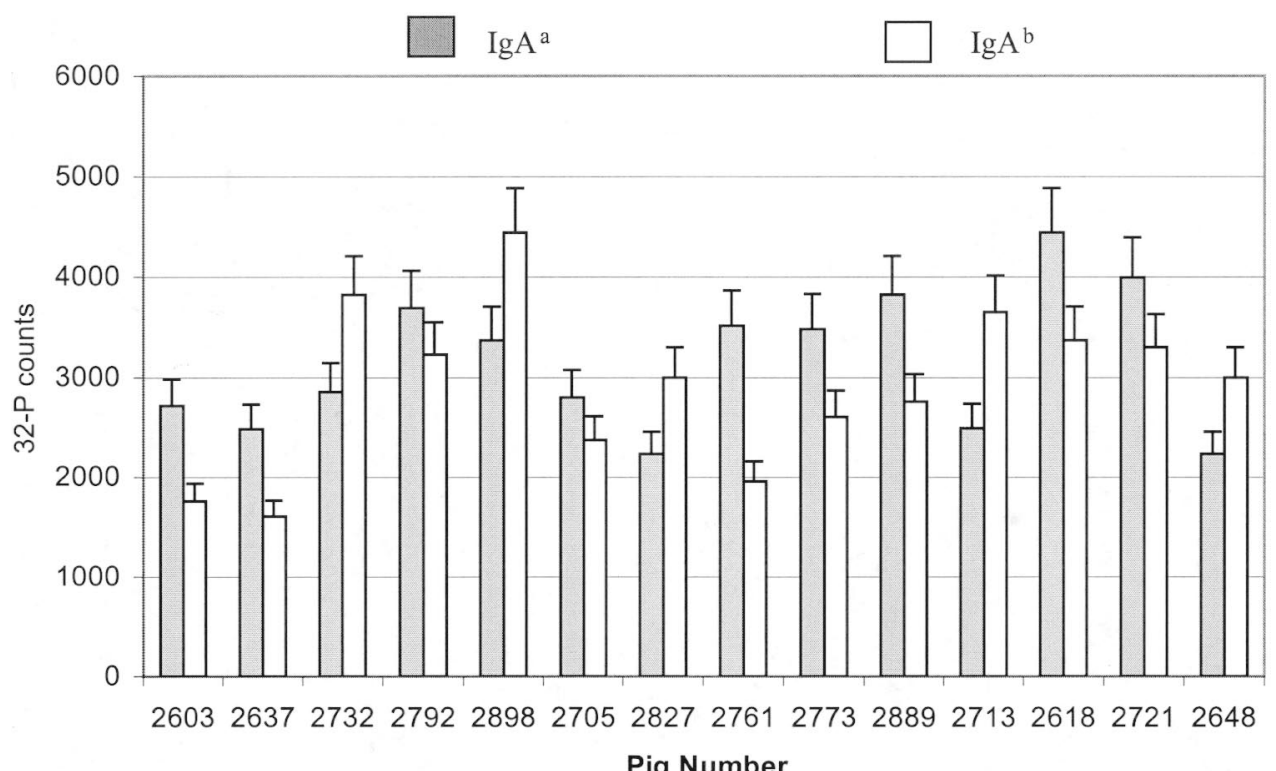

Fig. 5. IgA allotype distribution in PBLs from young old Duroc heterozygotes reared in Franklin, KY. The $Y$-axis shows the total counts for each PCR product. Since the results were obtained from a single measurement, the error was estimated by calculating the coefficient of variance (CF) of all previous RT-PCRs $(\mathrm{CF}=9.45 \%)$ and using this value to generate the error bars shown. Treated as a group in a two way ANOVA, $P=0.406$ indicating that the expression of transcripts for $\operatorname{IgA}^{\mathrm{a}}$ and $\operatorname{IgA}^{\mathrm{b}}$ did not significantly differ from a $1: 1$ ratio.

specific transcripts and the ratio of the allotype proteins in serum differed in $5 / 8$ of the animals and in all of the White Cross heterozygotes tested (Fig. 7B). In all cases in which these ratios differed, there was bias toward $\operatorname{Ig}^{\mathrm{a}}$ protein expression and this was especially pronounced in animal 21101.

\section{5. $\operatorname{Ig} A^{a}: \operatorname{Ig} A^{b}$ transcript ratios also differ in fetal piglets}

Fourteen different samples obtained from the spleen, thymus, mesenteric lymph nodes, ileal Peyer patches and parotid gland of five late-term heterozygous fetuses (110 days) were tested by RT-PCR and their allotype transcription ratios calculated. Since spleen and parotid were oligoclonal in terms of the CDR3 spectratype of their IgA transcripts, we focused on the IPP, MLN and thymus to avoid sampling bias resulting from too few clones. These tissues displayed a polyclonal or Gaussian distribution of CDR3 length in their IgA transcripts (Fig. 8). Of these tissues, the $\operatorname{Ig} \mathrm{A}^{\mathrm{a}}: \operatorname{Ig} \mathrm{A}^{\mathrm{b}}$ ratio differed significantly from 1:1 in the thymus of all animal tested (Fig. 9). Differences in ratios were also significant for other tissues, e.g. IPP of animal R1, although differences were not significant across all animals tested.

\section{Discussion}

The theoretical prediction of $1: 1$ expression of constant region allotypes in heterozygous animals assumes that: (a) productive VDJ rearrangements occur at ran- dom among chromosomes, (b) switch recombination is random, (c) the half-life of the two allelic transcripts is equal and (d) no selection for allele-encoded membrane-expressed gene products occurs. Assuming that selection of the B-cell receptor (BCR) depends on environmental antigen, fetal B-cells that have no access to an environmental antigen should exhibit perfect 1:1 allotype transcript ratios. While the most pronounced deviations were seen in highly polyclonal lymphoid tissues of animals exposed to environmental and maternal factors (Figs. 3 and 4) we also observed significant deviations in the thymus of late-term fetuses. In 5week-old Durocs, levels of $\operatorname{IgA}^{\mathrm{a}}$ up to 4-fold higher than $\operatorname{Ig} \mathrm{A}^{\mathrm{b}}$ were seen in every tissue tested. While a switch defect or a difference in transcript half-life was suspected, White Cross heterozygoes gave deviations of nearly equal magnitude in the opposite direction (Fig. 4). Thus, the skewed ratio observed among the Durocs is: (a) unlikely the result of an allotype-linked switch region defect as had been reported for human G3m (Pan et al., 1997), or (b) due to a difference in the half-life of the message. To distinguish the effect of breed versus environment, it would have been ideal to study Duroc animals from the Nebraska site and White Cross animals from Ames, IA. However, White Cross animals are found only at the Nebraska site. Thus, we tested 14 young heterozygous Duroc animals from Franklin, KY, and found that as a group, their $\operatorname{Ig}^{\mathrm{a}}: \operatorname{Ig} \mathrm{A}^{\mathrm{b}}$ ratios did not differ significantly from a $1: 1$ (Fig. 5). Despite this less than ideal experimental design, these results, as well as those from 8-week-old Durocs from ISU (Fig. 7B) provide no evidence to 
support the conclusion that biased transcription is breed dependent.

Since expression need not reflect levels of transcription, serum levels of $\operatorname{IgA}^{\mathrm{a}}$ and $\operatorname{Ig} \mathrm{A}^{\mathrm{b}}$ in the sera of heterozygous piglets were compared with $\operatorname{Ig} \mathrm{A}^{\mathrm{a}}: \operatorname{Ig} \mathrm{A}^{\mathrm{b}}$ transcript ratios in PBLs. Total serum IgA levels generally paralleled total transcription in PBLs regardless of genotype (Fig. 7A). This correlation might not be expected since $\operatorname{IgA}$ transcript levels in circulating $\operatorname{IgA}$ $(+)$ B-cells need not be representative of all lymphoid tissues that could contribute to serum IgA. In fact, 31\% of the $\operatorname{IgA}$ in swine serum originates from the intestine (Vaerman et al., 1997). The significant deviation favoring serum $\operatorname{IgA}^{\mathrm{a}}$ levels while transcript levels favor $\operatorname{Ig} \mathrm{A}^{\mathrm{b}}$ in White Cross piglets (Fig. 7B) may be the result of such a flawed comparison although in Durocs \# 1310 and \# 1303, skewing of transcript levels in PBLs was representative of all the lymphoid tissues tested (Fig. 3). Since we did not study transcript ratios in intestinal lymphoid tissue of White Cross animals, the excessive $\operatorname{Ig} \mathrm{A}^{\mathrm{a}}$ protein may be derived from the gut in these animals.

The differential transcription (and/or expression) of the IgA allotypes in young piglets could result from: (a) differences in cross-linking of IgA BCRs due to theoretical differences in hinge flexibility between porcine $\operatorname{IgA}{ }^{\text {a }}$ and $\operatorname{IgA}{ }^{\mathrm{b}}$, (b) linkage of an $\operatorname{IgA}$ allele to a $\mathrm{V}_{\mathrm{H}}$ allele in the same haplotype that encodes a specific BCR, (c) linkage between a IgA allotype and MHC class II, (d) postnatal maternal regulation, and (e) unequal cis/trans switching. The first possibility remains theoretical and entirely based on modeling from hinge region sequence data. Evidence in support of the second possibility is provided by studies of a-allotype expression in rabbits in which preferential usage of al also resulted in the preferential expression of $\mathrm{C} \gamma$ and $\mathrm{C} \alpha$ allotypes encoded in the same haplotype (Knight and Hanly, 1975; Mage, 1977). Similarly, the immune response of rabbits heterozygous for a light chain allotype show skewed expression in response to pneumococcal and streptococcal antigens (Catty et al., 1969; Kindt, 1974). If such a mechanism were responsible for the propensity of allotype expression in a certain breed of swine (Figs. 3 and 4), the selected allelic $V_{H}$ gene variants must be linked to $\operatorname{IgA}^{\mathrm{a}}$ in Durocs and $\operatorname{IgA}^{\mathrm{b}}$ in White Cross animals. Naturally, this could have been the result of a crossover in the common ancestral pig. Alternatively, the differences between Durocs and White Cross animals could reflect a difference in a major environmental antigen between the two sites. However, if environmental antigen selects certain VDJ-encoded BCR or selected BCRs because of hinge flexibility, it seems unlikely that the effect on IgA transcription would be the same at all anatomical sites (Fig. 3). Furthermore we show elsewhere that $>90 \%$ of the $\mathrm{V}_{\mathrm{H}}$ repertoire is determined by junctional diversity in CDR3, not be combinatorial diversity (Butler et al., 2000b). Thus, allotype expression by anti-allotypic antibodies (theoretical possibility ' $d$ ') should be considered since such suppression has been experimentally accomplished by administration of anti-allotype sera to neonatal rabbits (Dray, 1962). In the swine system, these anti-allotypic antibodies would have to be supplied via colostrum by the mother and there is no evidence from studies in any species that this naturally occurs. Lacking in the data presented is substantial evidence that $\operatorname{Ig} A^{\mathrm{a}}: \operatorname{Ig} \mathrm{A}^{\mathrm{b}}$ ratios

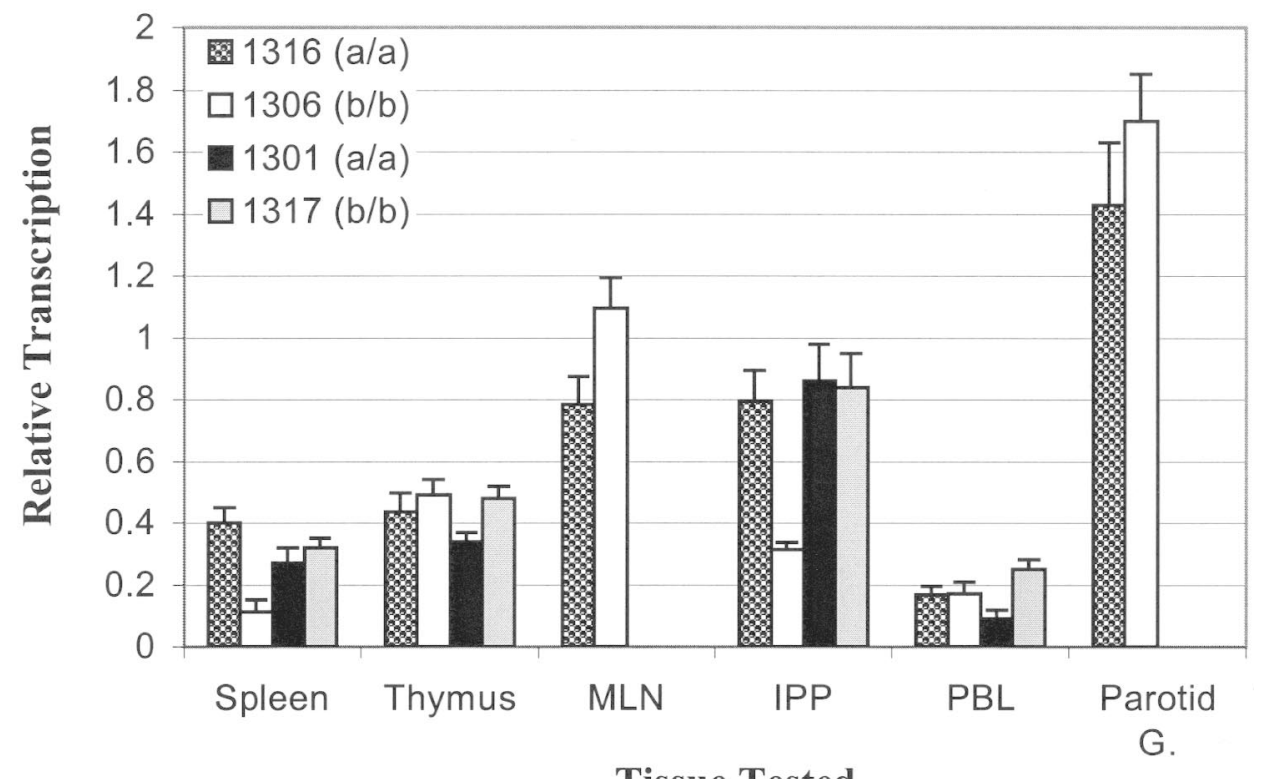

Fig. 6. Total relative IgA transcript levels in various tissues of four homozygous 5-week-old Duroc pigs of different genotype. The results shown are expressed as the mean and standard deviation. No MLN or parotid gland samples were available for animals 1301 and 1317. 

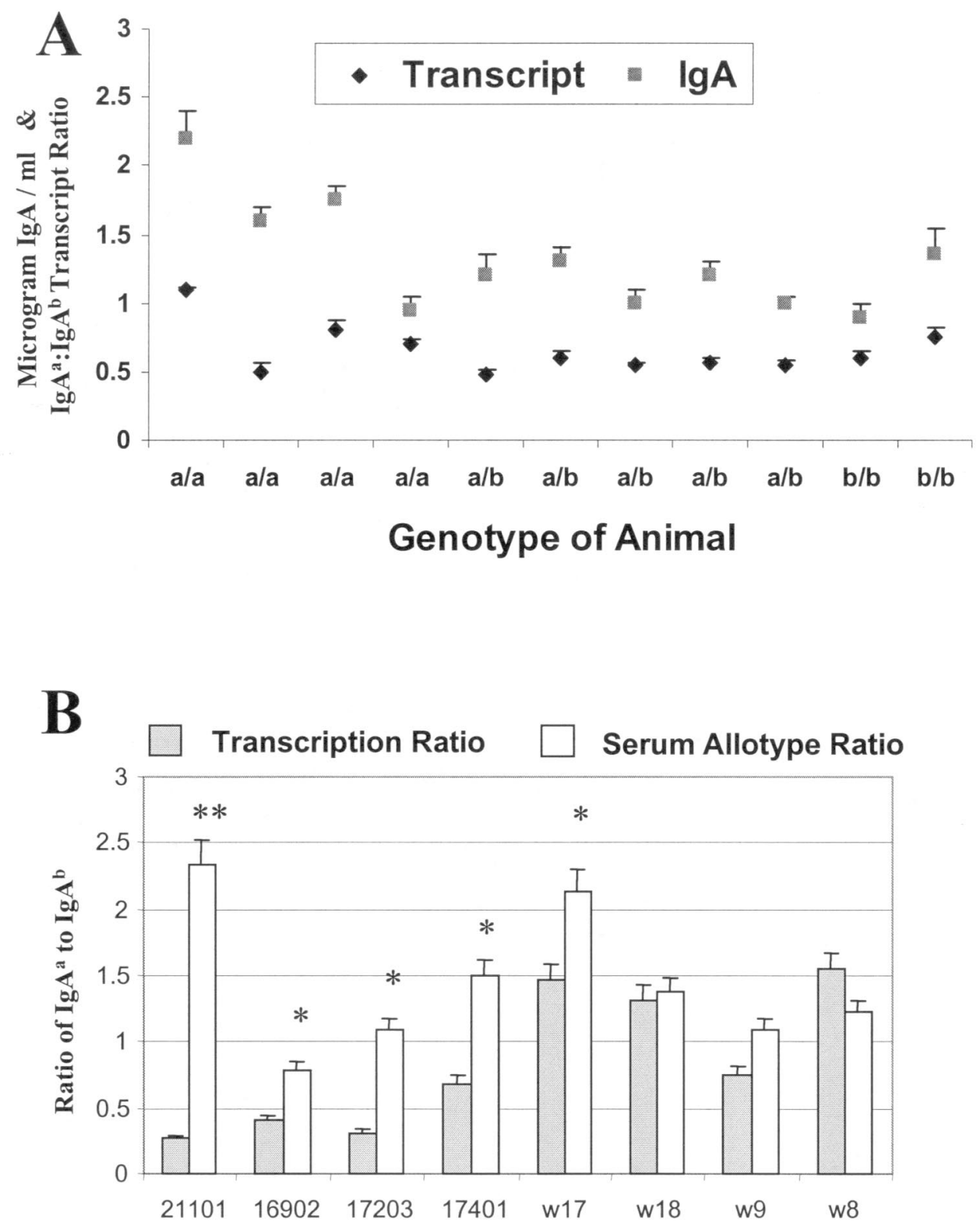

\section{Animal Tested}

Fig. 7. Serum IgA concentrations and relative IgA transcription by PBLs. (A) Comparison of total relative IgA transcript levels $(1=$ equal transcript frequency) and total serum IgA levels $(\mu \mathrm{g} / \mathrm{ml}$ using the same scale) in 8 -week-old Duroc pigs. Total serum IgA levels and total relative transcription in PBLs are significantly correlated; $P=0.015$. (B) Comparison of the ratio of $\operatorname{IgA}{ }^{\mathrm{a}}: \operatorname{Ig} \mathrm{A}^{\mathrm{b}}$ transcripts in PBLs and the ratio of $\operatorname{IgA}^{\mathrm{a}}: \operatorname{IgA}^{\mathrm{b}}$ in serum of the same heterozygous animals. Animals identified with only numbers are White Cross pigs from MARC (with ratios skewed to favor IgA ${ }^{\text {b }}$; see Fig. 4) while those with letters are 8-week Durocs from ISU in which transcript ratios seldom deviate from 1:1. The bars of the histogram represent the ratio of $\operatorname{IgA}^{\mathrm{a}}$ and $\operatorname{IgA}^{\mathrm{b}} .{ }^{*}$, Significantly different by Student's $t$-test at 0.05 . **, Significantly different by Student's $t$-test at 0.01 .

change during development (including during the postnatal period in which passive maternal antibodies could have an effect) and evidence that the allotype of the sow influences allotype expression in the suckling offspring. The observation that the skewed transcript ratios in 5-week-old Durocs from ISU were not present in an older litter, is provocative and could reflect the waning of maternal influence. Maternal $\mathrm{IgG}$ is ab- sorbed during the first $12 \mathrm{~h}$ after birth, reaches a level of $30 \mathrm{mg} / \mathrm{ml}$ in the sera of newborn piglets and has a serum half-life of 10.2 days (Klobasa et al., 1981).

While the Ig and MHC loci are linked on chromosome 7 in swine (Lunney and Butler, 1988) possibility ' $c$ ' is not supported by published data suggesting that MHC II usage is transcriptionally linked to the chromosome that has rearranged its VDJ. The first four 
theoretical explanations discussed above ignore the effect of trans-switching i.e. 'e', that has been observed in rabbits (Mage, 1977; Knight et al., 1995). In studies employing antisera specific for $\mathrm{V}_{\mathrm{H}}$ and $\mathrm{C}_{\mathrm{H}}$ allotypes, Tosi and Tosi (1973) reported that apparent transswitching recombinants accounted for $1 \%$ of rabbit serum IgG, while Pernis et al. (1973) using doublestaining fluorecence, reached a similar conclusion by immunohistochemistry. A slightly higher proportion of recombinants were reported by Dubiski (1969). Recombinant $\mathrm{V}_{\mathrm{H}} / \mathrm{C} \alpha$ molecules also accounted for ca. $2-6 \%$ of IgA molecules in the rabbit (Knight and Hanly, 1975). The latter observation has been shown to result from trans-switching rather than during VDJ rearrangement (Knight et al., 1995). Clearly, if the proportion of cis/trans switching varied considerably among IgA-producing cells, the deviation from a 1:1 ratio of $\operatorname{IgA}^{\mathrm{a}}: \operatorname{IgA}^{\mathrm{b}}$ transcripts, could be explained.

The role of thymic B-cells is not known, although their presence has been known for a long time (Dixon et al., 1957; Sante-Marie, 1965; Butler et al., 1972) but has recently attracted new interest (Henry, 1967; Henry and Anderson, 1989; Benjamini and Leskowitz, 1991; Cukrowska et al., 1996; McKenna and Morrissey, 1998; Akashi et al., 2000). In swine, switch recombination to $\mathrm{C} \alpha$ and $\mathrm{C} \gamma$ is a normal fetal event that occurs in utero in the absence of environmental antigen (Cukrowska et al., 1996; Sun and Butler, 1996; Fig. 8; Butler et al., 2000a) and the $\mathrm{C} \gamma$ and $\mathrm{C} \alpha$ repertoire in thymus is sufficiently polyclonal in late term fetuses (Fig. 8) to avoid sampling bias. Thus, the deviation in fetal thymus cannot be explained by selection of B-cells by environmental antigen. Perhaps deviations in fetal life result from selection by self or fetal B-cell superantigens. B-cell superantigens that recognize members of the $\mathrm{V}_{\mathrm{H}} 3$ gene family have been identified (Silverman, 1994; Silverman et al., 1995; Cary et al., 2000) and these can effect $V_{H}$ expression (Silverman et al., 1998). All swine $\mathrm{V}_{\mathrm{H}}$ genes are of the $\mathrm{V}_{\mathrm{H}} 3$ family and swine IgG competes favorably in binding assays with human $\mathrm{V}_{\mathrm{H}}$ 3-bearing Igs for the human fetal superantigen (Silverman, personal correspondence).

The data presented here indicate that IgA allotypes in heterozygotes are not equally transcribed or expressed. The observation that deviations in both directions from a 1:1 ratio of transcripts were seen (Figs. 3 and 4) are inconsistent with the concept of a switch recombination defect or a difference in transcript halflife. While stromal ligands in fetal life and environmental antigens in postnatal life are likely candidates, auto-anti-allotypic suppression should not be excluded as a possible explanation. Our finding provide the most quantitative data so far presented that the unequal allotype expression observed in earlier studies on rabbits, does indeed occur in conventionally-reared and even fetal animals in the absence of any apparent switch region defect. The isolator piglet model used by ourselves and others (Butler et al., 2000b) can provide an excellent opportunity to investigate the role of environment and maternal factors on allotype expression in piglets heterozygous for the alleles of IgA in highly controlled experiments.

\section{Acknowledgements}

The authors thank Jon Yankey, Department of Biostatistics and Dr Jon Lemky, Department of Preventive Medicine for assistance with statistical analyses, Jishan Sun, Department of Microbiology for advice concern-

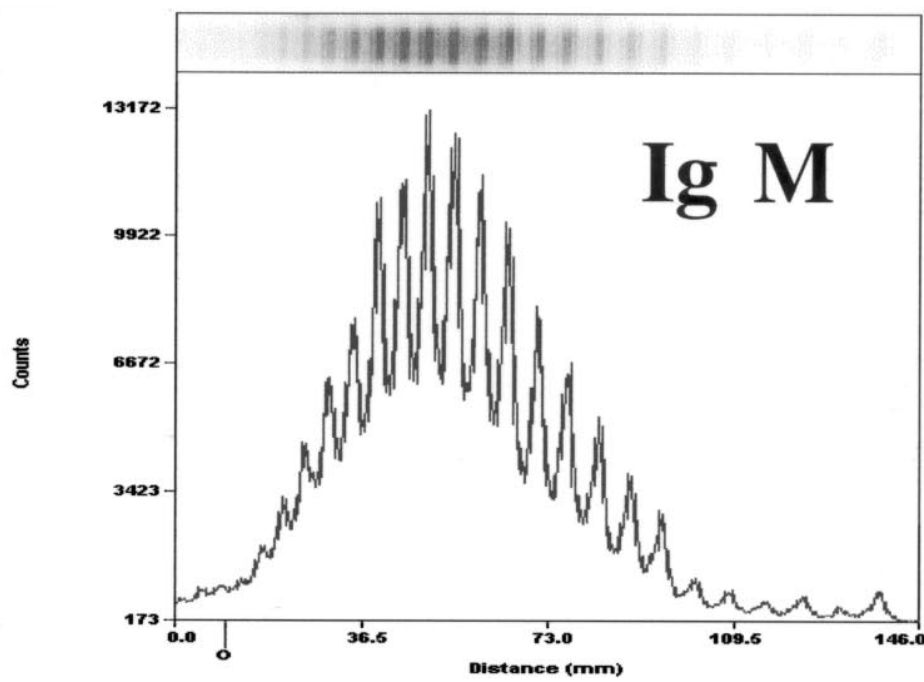

Fig. 8. Spectrotypic (CDR3 length) analysis of IgA (left) and IgM (right) transcripts from the thymus of a late term fetal piglet. The gel electrophoretic results are shown above and the density scan shown below. A similar pattern was seen in the ileal Peyers patches. 


\section{IPP a $\square$ IPP b $\square$ MLN a $\square$ MLN b $\quad$ Thymus a $\square$ Thymus b}

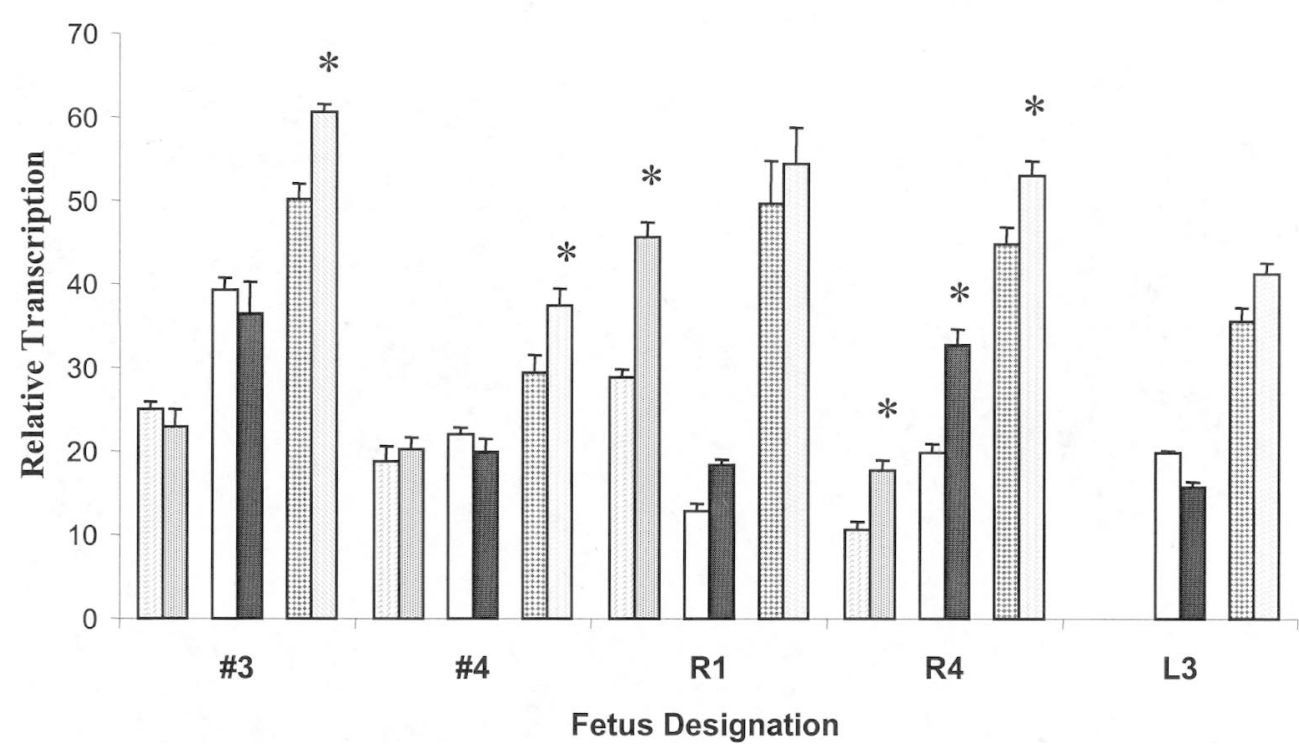

Fig. 9. Relative transcription of IgA allotypes in various lymphoid tissues from five 110-day fetal piglets designated \# 3, \# 4, R1, R4 and L3. Mean values \pm S.D. are the result of triplicate assays. IPP, ileal Peyers patches; MLN, mesenteric lymph node. The small letters ' $a$ ' and ' $b$ ' designate the two IgA alleles. Using a split-plot ANOVA, the only difference in transcript ratio that was consistent for all animals was in the thymus. Differences in transcript ratios for individual animals were seen, e.g. IPP and R1 or MLN for R4, but these differences were not consistent across animals.

ing RT-PCR and Marcia Reeve for preparation of the typescript. Research supported by a grant from the Iowa Pork Producers Council, from USDA-NRI grant 970-2612 and through an agreement with PIC and MARC.

\section{References}

Akashi, K., Richie, L.I., Miyamoto, T., Carr, W.H., Weissman, I.L., 2000. B lymphophoiesis in the thymus. J. Immunol. 164, 52215226.

Benjamini, E., Leskowitz, S., 1991. The ontogeny of cells involved in the immune response. In: Immunology: A Short Course, 2nd edn. Wiley-Liss, New York, pp. 154-160.

Brown, W.R., Butler, J.E., 1994. Characterizaiton of a $\mathrm{C} \alpha$ gene of swine. Mol. Immunol. 31, 633-642.

Brown, W.R., Kacskovics, I., Amendt, B., et al., 1995. The hinge deletion variant of porcine $\operatorname{IgA}$ results from a mutation at the splice acceptor site in the first $\mathrm{C} \alpha$ intron. J. Immunol. 154, 3836-3842.

Butler, J.E., Maxwell, C.F., Pierce, C.S., Hylton, M.B., Asofsky, R., Kiddy, C.A., 1972. Studies on the relative synthesis and distribution of $\operatorname{IgA}$ and $\operatorname{IgG1}$ in various tissues and body fluids of the cow. J. Immunol. 109, 38-46.

Butler, J.E., Sun, J., Weber, P., Christenson, R., Ford, S.J., 2000a. Antibody repertoire development in fetal and neonatal piglets. IV. The concentration of $\operatorname{IgM}, \operatorname{IgG}$ and $\operatorname{IgA}$ in fetal serum and the level of transcription of these Igs in various fetal lymphoid tissues, J. Immunol. (in press).

Butler, J.E., Weber, P., Sinkora, M., Sun, J., Ford, S.J., Christenson, R., 2000b. Antibody repertoire development in fetal and neonatal piglets. II. Characterization of heavy chain CDR3 diversity in the developing fetus. J. Immunol. 165, 6999-7010.
Cary, S.P., Lee, J., Wagenknecht, R., Silverman, G.J., 2000. Characterization of superantigen-induced clonal deletion with a novel clan III-restricted avian monoclonal antibody: exploiting evolutionary distance to create antibodies specific for a conserved VH region surface. J. Immunol. 164, 4730-4741.

Catty, D., Humphrey, J.H., Gell, P.G.H., 1969. The proportion of two b locus allotypic determinants in rabbit antisera raised against pneumococcal polysaccharide SSS3 antigen. Immunology 16, 409-422.

Cukrowska, B, Sinkora, J, Mandel, L, et al., 1996. Thymic B cells of pig fetuses and germ-free pigs spontaneously produce IgM, IgG and IgA: detection by ELISPOT method. Immunology 87, 487492.

Dixon, F.J., Weigle, W.O., Roberts, J.C., 1957. Comparison of antibody responses associated with the transfer of rabbit lymph node, peritoneal exudate and thymus cells. J. Immunol. 78, 5663.

Dray, S., 1962. Effect of maternal isoantibodies on the quantitative expression of two allelic genes controlling gamma-globlin allotypic specificities. Nature (Lond.) 195, 677-680.

Dubiski, S., 1969. Immunochemistry and genetics of a 'new' allotypic specificity $\mathrm{A}_{\mathrm{e}}^{14}$ of rabbit $\gamma \mathrm{G}$ immunoglobulins: recombination in somatic cells. J. Immunol. 103, 120-128.

Grubb, R.E., 1994. Human immunoglobulin allotypes and Mendelian polymorphisms of the human immunoglobulin genes. In: van Oss, C.J., Van Regenmortel, M.H.V. (Eds.), Immunochemistry. Marcel Dekker, New York, pp. 47-68.

Hassan, M.S., Islam, K.B., Hammarström, L., Edvard Smith, C.I., 1992. Regulation of $\mathrm{C} \gamma 3$ expression. Role of switch in the allotype-associated variation of human serum $\mathrm{IgG} 3$ levels. J. Immunol. 148, 2555-2562.

Henry, L., 1967. Involution of the human thymus. J. Pathol. Bacteriol. 93, 661-671.

Henry, L., Anderson, G., 1989. Immunoglobulin-producing cells in the human thymus. Thymus 12, 77-87. 
Janeway, C.A., Jr, Travers, P., 1996. Immunobiology, 3rd edn. Garland Press, New York.

Kindt, T.J., 1974. Allelic selection of light chain allotypes by antibodies raised in heterozygous rabbits. J. Immunol. 112, 601-606.

Klobasa, F., Werhahn, E., Butler, J.E., 1981. Regulation of humoral immunity in the piglet by immunoglobulins of maternal origin. Res. Vet. Sci. 31, 195-206.

Knight, K.L., Hanly, W.C., 1975. Genetic control of $\alpha$-chains of rabbit IgA: Allotype specificities on the variable and the constant regions. Contem. Top. Mol. Immunol. 4, 55-88.

Knight, K.L., Kingzette, M., Crane, M.A., Zhai, S.-K., 1995. Transchromosomally derived Ig heavy chains. J. Immunol. 155, 684691.

Lunney, J., Butler, J.E., 1988. Immunogenetics. In: Rothschild, M.F., Ruvinsky, A. (Eds.), Genetics of the Pig. CAB International, Willingford, UK, pp. 163-197.

Lyman, R., 1993. In: Lozyaniak, K., Krikorian, S. (Eds.), An Introduction to Statistical Methods and Data Analysis. Duxburry Press, Belmont, CA., pp. 357-361.

Mage, R.G. (1977). Structure and expression of $V_{H}$ and $C_{H}$ allotypic determinants. In: Mandal, T.E., Cheers, C., Hosking, C.S., McKenzie, I.F.C., Nossal, G.J.V. (Eds.), Progress in Immunology III. Australia Academy of Science, Academic Press, New York, pp. 289-297.

McKenna, H.J., Morrissey, P.J., 1998. Flt3 ligand plus IL-7 supports the expansion of murine thymic B cell progenitors that can mature intrathymically. J. Immunol. 160, 4801-4809.

Melchers, F., Haasner, D., Grawunder, U., et al., 1994. Roles of IgA and $\mathrm{L}$ chains and of surrogate $\mathrm{H}$ and $\mathrm{L}$ chains in the development of cells in the B lymphocyte lineage. Ann. Rev. Immunol. 12, $209-225$.

Morel, A., Skvaril, F., Steinberg, A.G., van Loghem, E., Terry, W.D., 1972. Correlation between the concentrations of the four subclasses of $\mathrm{IgG}$ and $\mathrm{Gm}$ allotypes in normal human sera. J. Immunol. 108, 195-206.

Navarro, P., 1998. The allelic hinge variants of swine IgA. MS Thesis, The University of Iowa.
Navarro, P., Christenson, R.K., Ekhardt, G., et al., 2000. Genetic differences in the frequency of the hinge variants of porcine $\operatorname{IgA}$ is breed dependent. Vet. Immunol. Immunopathol. 73, 287-295.

Pan, Q., Rabbani, H., Hammerström, L., 1998. Characterization of human $\gamma 4$ switch region polymorphism suggests a meiotic recombinational hot spot within the Ig locus: Influence of $\mathrm{S}$ region length on IgG4 production. J. Immunol. 161, 3520-3526.

Pan, Q., Rabbani, H., Mills, F.C., Severinson, E., Dunnick, W., 1997. Allotype-associated variation in the human $\gamma 3$ switch region as a basis for differences in IgG3 production. J. Immunol. 158, 58495859.

Pernis, B., Forni, L., Dubiski, S., Kelus, A.S., Mandy, W.J., Todd, C.W., 1973. Heavy chain varilable and constant region allotypes in single rabbit plasma cells. Immunochemistry 10, 281-285.

Sante-Marie, G., 1965. Plasmacytes in the thymus of the normal rat. J. Immunol. 94, 172-174.

Silverman, G.J., 1994. Superantigens and the spectrum of unconventional B-cell antigens. Immunologist 2, 51-55.

Silverman, G.J., Roben, P., Bouvet, J-P., Sasan, M., 1995. Superantigen properties of a human sialoprotein involved in gut-associated immunity. J. Clin. Invest. 96, 417-426.

Silverman, G.J., Nayak, J.V., Warnatz, K., et al., 1998. The dual phases of the response to neonatal exposure to a VH family-restricted Staphylococcal B-cell superantigen. J. Immunol. 161, $5720-5732$.

Sun, J., Butler, J.E., 1996. Molecular analysis of VDJ transcripts from a newborn piglet. Immunology (Br.) 88, 331-339.

Tosi, S.L., Tosi, R.M., 1973. Recombinant IgG molecules in rabbits doubly heterozygous for group a and group e allotypic specificities. Immunochemistry $10,65-72$.

Vaerman, J.-P., Langendries, A., Pabst, R., Rottkotter, H.J., 1997. Contribution of serum IgA to intestinal lymph IgA and vice versa in minipigs. Vet. Immunol. Immunopath. 58, 301-308.

Yount, W.J., Kunkel, H.G., Litwin, S.D., 1967. Studies of the Vi (gamma-2c) subgroup of G-globulins. A relationship between concentration and genetic type among normal individuals. J. Exp. Med. 125, 177-190. 